\title{
Comunicación de Gobierno: reflexiones en torno a un objeto
}

\author{
José Luis FERNÁNDEZ ${ }^{1}-$ Beatriz SZNAIDER $^{2}$ \\ UBA. Facultad de Ciencias Sociales, Ciencias de la Comunicación
}

\begin{abstract}
RESUMEN:
El objetivo de este trabajo es describir desde una perspectiva sociosemiótica, el origen y las transformaciones de uno de los recursos centrales de los gobiernos para tomar contacto con sus públicos, como es el aviso en la prensa. Bajo este género reunimos un conjunto de textos que con voluntad informativa fueron generando las instituciones gubernamentales en distintos períodos, desde la consolidación de la prensa independiente, comercial, profesional y masiva en la República Argentina, a principios del siglo XX, hasta la actualidad, centrándonos en la comunicación de gobierno de la Ciudad Autónoma de Buenos Aires. Puestos en sistema, los avisos de gobierno pueden leerse como narración autorreferencial de las instituciones del Estado; como reservorio de un conjunto amplio de tópicos sobre lo público; y como un régimen de comunicación para la construcción de lo común. La vocación informativa de las instituciones de gobierno nunca está exenta de registros propios del discurso publicitario y del discurso político. Y es en las campañas comunicacionales cuando esos registros pueden asomar con mayor fuerza. Para recorrer estos textos tendremos en cuenta sus modos particulares de procesar los estilos gráfico-argumentativos propios de cada período, efecto de operaciones enunciativas.
\end{abstract}

PALABRAS CLAVE: Comunicación; Gobierno; Aviso; Géneros; Estilos.

TITLE: Government communication: reflections about an object

\begin{abstract}
:
The aim of this work is to describe, from a socio-semiotic perspective, the origin and transformations of one of the main government's recourses to relate with its public: the press advertisement. Under this genre, we gather a group of texts which, with the goal of being informative, were produced by governmental institutions in different periods of time, from the consolidation of independent, commercial, professional and massive press in Argentina, at the beginning of the XX century to current time, focusing on the communication of the government of the City of Buenos Aires. Placed on system, government's advertisements might be read as a self-referenced narration about the state institutions; as a reservoir of a wide set of topics regarding the public sphere; and as a communication regime for the construction of the common thing. The informative vocation of governmental institutions is never extent from hues related to advertising discourse and the political discourse. It is in the communicational campaigns when those hues arise with more
\end{abstract}

1 José L. Fernández es doctor en Ciencias Sociales, UBA. Titular de Semiótica de los Medios de la Facultad de Ciencias Sociales, UBA; investigador y formador de investigadores. Dirige el proyecto de investigación "Letra, Imagen, Sonido: Convergencias y divergencias en los medios y en el espacio urbano" y es director de la Revista "L.I.S. Ciudad Mediatizada". Ferrari 206 P. 7 Dto. B (1414) CABA $54114854-8487$ j_fernandez@szinfonet.com.ar

2 Beatriz Sznaider es licenciada en Ciencias de la Comunicación, UBA. Docente de Semiótica de los Medios de la Facultad de Ciencias Sociales, UBA, e investigadora formada. Integra el proyecto de investigación "Letra, Imagen, Sonido: Convergencias y divergencias en los medios y en el espacio urbano" y forma parte del Consejo de Redacción de la Revista "L.I.S. Ciudad Mediatizada". Aranguren 56 (1405) CABA 5411 4983-0451 bsznaider@fibertel.com.ar 
strength. To work on these texts, we will take into account their specific ways of processing the graphicargumentative styles in each period, as a result of enunciative operation.

KEY WORDS: Communication; Government; Advertisement; Genres; Styles.

\section{Introducción}

Entendemos la comunicación de gobierno como una dimensión de la cultura políti$c a$ que atiende a las «formas de intervención de los lenguajes y las culturas en la constitución de los actores del propio sistema político». ${ }^{3}$ Es en los avisos de gobierno, entre otras prácticas comunicacionales propias de este tipo de institución, donde «cobran forma los discursos que deben construir y hacer evolucionar el vínculo entre los ciudadanos y sus representantes». ${ }^{4}$

Algunas de las dificultades para comprender el alcance de la comunicación de gobierno se centran en que como práctica, ésta parece desbordar cualquier descripción. Es que todo elemento de la institución de gobierno comunica: la falta de palabra o posición pública de las autoridades frente a una situación de crisis; un servicio que no funciona adecuadamente o el proceder privado de un funcionario público pueden operar como marcas inorgánicas que igualmente significan,

Frente al carácter extendido de este tipo de comunicación, los géneros discursivos - producto de prácticas sociales específicas y situadas-, constituyen un punto de partida y base material para su estudio. ${ }^{5}$

El aviso de gobierno emplazado en la prensa moderna ha sido el primer recurso de las autoridades para tomar contacto con sus públicos en forma masiva. Y a pesar del privilegio que ha adquirido Internet en los últimos años y del peso social que sigue teniendo la televisión generalista, los diarios continúan siendo el soporte donde obligatoriamente los gobiernos e instituciones públicas deben publicar cierto tipo de información, por ejemplo, la vinculada a licitaciones y concursos públicos.

La comunicación de gobierno contemporánea funciona casi siempre en sistema, a través de campañas generales donde junto con los avisos en la prensa pueden aparecer afiches en vía pública, spots televisivos y radiales, banners, folletos, etc. A pesar de una presencia persistente y a veces profusa en los medios de comunicación y en el espacio público, los géneros de la comunicación de gobierno han generado una memoria breve, salvo cuando se los vio como puro intento apologético y explícitos engranajes del ho-

\section{VERÓN, E. (2001): El cuerpo de las imágenes, Buenos Aires, Norma, 39. \\ Ibidem, 39.}

Los géneros son clasificaciones sociales de los lenguajes que presentan regularidades en sus modos de desempeño semiótico. Como instancias estables y permanentes de organización y estructuración intratextual, desempeñan una función reguladora de los usos del lenguaje, al modo de una institución, en una comunidad histórica específica en: BAJTIN, M. M. (Varias ediciones): «El problema de los géneros discursivos» en Estética de la creación verbal. México. Siglo XXI Editores y SteImberG, O. (1993) «Proposiciones sobre el género» en Semiótica de los medios masivos, Buenos Aires, Atuel. 
rror: fascismos, guerras, dictaduras, etc. $\mathrm{O}$ cuando trascendieron por su carácter paradojal (sobrepromesa; descontextualización; etc.). De esta mirada anatemizada parece provenir cierta ausencia de un abordaje sistemático.

Para la doxa, la comunicación de gobierno debería estar tan lejos de la publicidad como de la propaganda. En esta idea parece funcionar el temor de gran parte de la sociedad a los efectos enunciativos del lenguaje publicitario; temor a que el poder de su retórica encubra u oculte la «verdadera» intención de la institucional o debilite las condiciones de pedagogicidad republicana que idealmente la comunicación de gobierno debería encarnar. Pero este temor también funciona en las instituciones republicanas que a través de distintas leyes tratan de regular sus contenidos para diferenciar y separar comunicación gubernamental de comunicación partidaria $^{6}$.

Dónde colocar entonces a la comunicación de gobierno respecto de posibles formas de «influencia o manipulación» de la publicidad y de la propaganda. Cuáles son los límites entre cada una y las comparaciones que se pueden establecer. De estos problemas surgen una cantidad de preguntas específicas: ¿se puede/debe «vender» a un presidente como si fuese un producto? ¿comunicar la inauguración de una obra pública es información o propaganda? ¿la comunicación de gobierno debe/puede alejarse de cualquier poeticidad o juego retórico?

A modo de recordatorio, la publicidad es entendida de manera básica como una forma de comunicación comercial destinada a dar a conocer un producto, emergente del sistema de producción capitalista.

Respecto de la propaganda, se suele asociar con la difusión o imposición de ideas políticas, filosóficas, morales, sociales o religiosas a través de formas persuasivas y disuasivas ${ }^{7}$. Para Domeneach, «la propaganda puede compararse con la publicidad en cuanto tiende a crear, transformar o confirmar opiniones y usa algunos de los medios propios de ésta» ${ }^{8}$; pero se distingue de ésta por sus fines.

La institución de gobierno siempre se hace presente en su propio discurso a través de modalizaciones que, intencionalmente o no, construirán un vínculo entre gobernante y gobernado. Y ante una estrategia comunicacional, sus avisos se pue-

6 «Los mensajes o la presentación de las campañas institucionales de publicidad y de comunicación no podrán inducir a confusión con los símbolos, ideas, expresiones, diseños o imágenes empleadas por cualquier formación política u organización social». Art. 4 de la Ley de Publicidad y Comunicación Institucional de España (29/2005). En la Argentina no existen normas federales de regulación, pero sí municipales, en: BuRGOS, M. y DíAZ CAFFERATA, S. (2009) «La regulación de la publicidad oficial en Argentina»; Etica, Transparencia, Corrupción y Control Ciudadano, www.asociacionag.org.ar. Web visitada el 19/12/2011.

7 José L. Fernández establece las diferencias entre persuasión y disuasión en toda acción comunicacional, cuando se intenta vencer la resistencia de los receptores atacando los núcleos argumentativos tratando de cambiar su estructuración; o quitando espacio a las manifestaciones de resistencia mediante la saturación del espacio conceptual-discursivo, respectivamente, en FERNÁNDEZ J. L. (1995): «Estilo discursivo y planeamiento comunicacional», Oficios Terrestres 1, La Plata, UNLP.

8 Domeneach, J.-M. (1962): La Propaganda Politica. Buenos Aires, Editorial Buenos Aires, 3. 
den investir de rasgos estilísticos que pongan en juego algún tipo de interfaz con aspectos del discurso publicitario o político.

Entre la comunicación comercial y la comunicación política podemos pensar un espacio en el que se ubica la comunicación de gobierno y toda la comunicación de instituciones públicas, de organizaciones no gubernamentales, de instituciones de bien público y aún, de la comunicación no comercial de empresas, y que se denomina genéricamente comunicación institucional. Las clasificaciones comunicación comercial, institucional y política atienden tanto al carácter de las instituciones responsables, como a sus intenciones. Pero desde su funcionamiento significante, esas categorías tienden a dialogar.

Inicialmente postulamos que la comunicación de gobierno puede articular con recursos de la comunicación comercial y política a partir de un exceso retórico vinculado sobre todo a procesos de figuración y argumentación. Esos procesos pueden generar gratuidad enunciativa en relación al lugar de la institución que queda en primer plano respecto del componente informativo, de los asuntos de interés público o de bien común.

Para un abordaje metodológico de esos textos y para evitar cualquier desviación inmanentista, la comunicación institucional -igual que la comercial o la política- no puede ser estudiada como algo dado, a partir del propósito manifiesto de sus emisores «empíricos». Sino que debe ser abordada como proceso comunicacional denso y no lineal, cuyo «contenido» debe considerarse dentro del soporte y dispositivo técnico en el que se instala, de los géneros que la organizan y de la dimensión estilística en que se inscribe. Es decir, los condicionamientos y efectos sociales con los que se interpenetran. El recorrido de un mensaje no es independiente de ninguna de esas instancias.

La institución, ya no en su condición de emisor responsable sino como figura "abstracta", "teórica", producto de su propio acto de enunciación, se inscribe en su discurso y construye una imagen de sí misma y de aquel a quién se dirige; además de construir también una imagen del afuera social donde se juega ese vínculo entre gobernante y gobernado y a través de dispositivos que podrán ser o no de carácter lingüístico?.

Aunque el concepto de enunciación supone un orden no intencional, todas las formas planificadas de comunicación o «formas controladas» ${ }^{10} \mathrm{y}$-aún más aquellas que se despliegan a nivel de las campañas- «sueñan» con clausurar la interpretación infinita propia de la semiosis y trabajan con recursos provenientes de distintos campos del saber para acortar la distancia entre intención y efectos. Sin embargo, el reconocimiento del «trabajo» de las instituciones de gobierno sobre su lenguaje no transparenta el problema de su interpretación, sólo lo pone en superficie.

\footnotetext{
9 Steimberg, O. (1993): op. cit.

10 Traversa, O. (2009): «Dispositivo-enunciación: en torno a sus modos de articularse» en Revista Figuraciones, Buenos Aires, IUNA, http://www.revistafiguraciones.com.ar/numeroactual/index.php?idn=6\&arch=1 Web visitada el 16/8/2011.
} 
Como rasgo retórico-estilístico, tendremos en cuenta que al grado 0 de la comunicación comercial, institucional y de gobierno casi siempre se le superponen distintos niveles significantes que definimos como dimensiones. Así, en toda comunicación comercial podrá leerse algún registro propio de lo institucional o lo político; en toda comunicación institucional podrá leerse algún registro propio de lo comercial o lo político y así de seguido.

El concepto de estilo, de gran tradición dentro de los estudios del arte, nos permite clasificar discursos, de la misma manera que los géneros, aunque su condición productiva va más allá y abarca también prácticas sociales, en general. ${ }^{11}$ Pero como efecto (y también como causa) de las condiciones particulares de los contextos históricos y culturales, el estilo se puede asociar más fuertemente a las condiciones del cambio y del carácter original de cada momento de producción discursi$\mathrm{va}^{12}$. El concepto también es importante porque nos «permite constituir segmentos de población diferenciados en el nivel el discursivo» ${ }^{13}$ a partir de los textos que estos consumen, valoran y generan.

La noción de estilo permitirá entonces describir las transformaciones discursivas del género aviso de gobierno y de las campañas comunicacionales que los contuvieron a partir de sus configuraciones retóricas. También, de los modos de tematizar asuntos permanentes o novedosos de gobernabilidad y gobernanza y las relaciones entre enunciador y enunciatario construido, que casi siempre son las que definen con mayor nitidez las diferencias estilísticas interinstitucionales.

Para comenzar a delimitar nuestro objeto planteamos que la comunicación de gobierno puede ser pensada a partir de sus distintas facetas. En un orden que no supone jerarquía, una (a) faceta administrativa, una (b) faceta institucional y una (c) faceta política.

Se puede describir la (a) faceta administrativa como estrictamente instrumental, en tanto todo gobierno es una organización sujeta a fines. Por lo que a partir del ejercicio de un conjunto de actos cotidianos, se le impone la necesidad de informar a la población sobre distintos asuntos como la fecha de pago de un impuesto, la puesta en marcha de un servicio, el cambio de horario de atención de una dependencia gubernamental, etc.

En segundo lugar, reconocemos una (b) faceta institucional, ya que todo sistema democrático tiene en la publicidad de los actos de gobierno una de sus obligaciones constitucionales. ${ }^{14}$ Dicha publicidad conforma uno de los principios que marcan la transición del Estado absolutista al Estado de derecho como recurso fun-

11 Por ejemplo: la cocina, la moda, la arquitectura, etc. Además, al nuclear distintos campos de desempeño social, estos se pueden vincular por su pertenencia a un mismo estilo, por ejemplo, barroco, minimalismo o punk.

12 SteimberG, O. (1993): op. cit.

13 FERNÁNDEZ, J. L. (1995): op. cit.

14 Nos referimos a la faceta institucional de un cierto tipo de comunicación institucional. La reiteración de los términos deja abierto el debate para un perfeccionamiento de la terminología o una redefinición de la categoría. 
damental para «develar lo oculto», en el sentido kantiano de hacer públicos todos los actos de gobierno. Y se completa en el constitucionalismo moderno con el derecho de libre acceso a la información pública administrada por el Estado, como mecanismo de control y de participación ciudadana.

Dentro de ese orden institucional se podrían ubicar tanto los anuncios vinculados a medidas generales, intervenciones y obras de mediano o gran alcance, así como todas las acciones persuasivas por las que el gobierno -que cuenta con el poder delegado que le confiere la sociedad y con los recursos económicos para intervenir en la trama comunicacional- busca convencer a algún sector de la población para que modifique conductas, adhiera, se informe o actúe en función de intereses propios o generales. Por ejemplo: campañas por el uso del cinturón de seguridad, del preservativo o para la vacunación contra el VIH Sida; el anuncio de la realización de obras significativas; la promoción de formas de democracia semidirecta como un plebiscito, una consulta popular, etc.

Ese deber ser administrativo e institucional de la comunicación de gobierno no puede dejar de lado aspectos centralmente políticos de la acción gubernamental en las sociedades de masas por los que una gestión, mientras sostiene la utopía de gobernar para todos ${ }^{15}$, actúa siempre afectando intereses de un sector de la sociedad respecto de otro. Desde esa condición queda relegado el componente informativo para transmitir como concepto central la idea de que «se está gobernando»y además, «se está gobernando bien».

Así, como tercera faceta, aparece la (c) faceta política por la que todo gobierno despliega un conjunto de estrategias comunicacionales para generar cierto consenso social que fortalezca la legitimidad de sus decisiones sino para obtener adhesiones, al menos para generar un efecto de gobernabilidad y, aún, para construir un adversario. Porque como se presenta en El Príncipe, «si (...) es imposible ganarse el amor del pueblo consiga evitar el odio, porque puede combinarse perfectamente el ser temido y el no ser odiado». ${ }^{16}$

Lo que habilita esa enunciación dentro de la comunicación de gobierno es justamente la presencia de marcas del discurso político como el tópico de la promesa, o la representación de un otro a quién se puede inscribir enunciativamente de manera positiva o negativa.

Como ejemplo de una representación positiva, el eslogan del gobierno argentino presente en todas las piezas institucionales desarrolladas para el Bicentenario de la Nación (1810-2010), "Fuimos capaces. Somos capaces». El eslogan trabajaba desde un nosotros inclusivo que generaba horizontalidad y acortaba la distancia entre el emisor institucional, la Presidencia de la Nación, y el enunciador construi-

15 Y aquí entran un conjunto de declinaciones como «gobernar para las grandes mayorías», «por el bien de la Patria», «trabajar para la gente», etc.

16 Maquiavelo, N. (1989): El Príncipe. México, Editorial Porrúa, Cap. XVII, 45-46. 
do: una voz colectiva - un colectivo de identificación, como lo formula Verón- ${ }^{17}$ que interpelaba desde la motivación. Pero además, «la proposición dejaba en suspenso la proyección sobre el futuro, por lo que imponía un espacio sin coerción ni sobrepromesa para imaginar (lo) el porvenir ${ }^{18}$.

Como ejemplo de una representación negativa, el eslogan empleado para un aviso publicado en 1940 por el Ministerio de Agricultura de la Nación para la empresa YFP (Yacimientos Petrolíferos Fiscales) «No tenemos otro sello», que operaba en una función de relevo. Se trata del escudo nacional presentado a partir de un detalle de la fachada del edificio de YPF. Una doble sinécdoque construía al edificio de la empresa como la empresa toda; y al escudo como condensación de la identidad nacional. En esa operación de investimiento, la empresa parece hacerse cargo de una cierta esencialidad de «lo argentino» que compone como antagonista de cualquier perspectiva de sesgo liberal que se oponga a los principios estatistas que orientan la gestión de la empresa. Desplazadamente, lo liberal queda construido como «lo no argentino».

Fig. 1 Yacimientos Petroliferos Fiscales. Diario La Nación, 25/05/1940

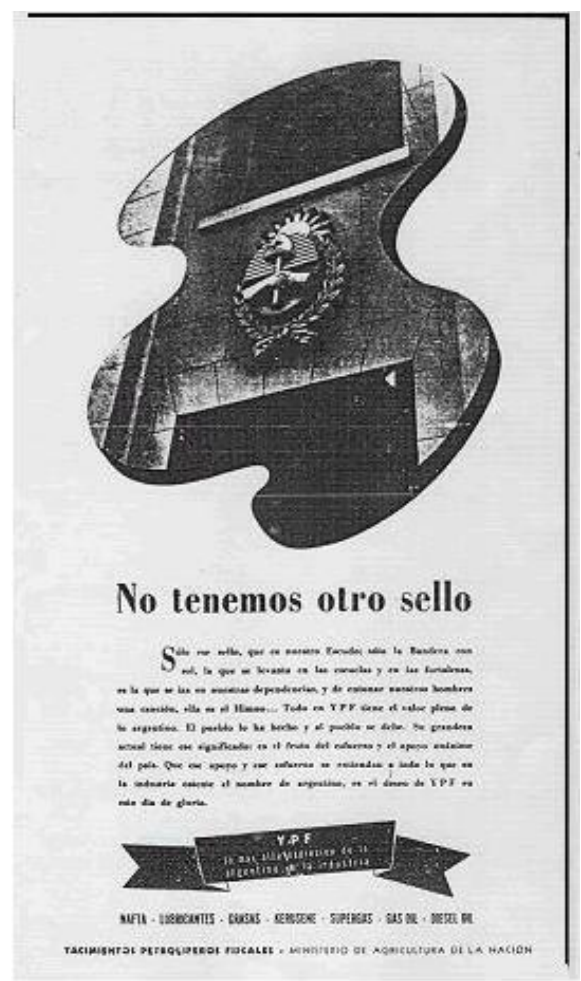

17 VERÓN, E. (1987): «La palabra adversativa. Observaciones sobre la enunciación política» en El discurso político. Lenguajes y acontecimientos, AA.VV., Buenos Aires, Hachette.

18 SznAider, B. (2010): «Bicentenario. Pliegues de la Argentina sus avisos institucionales» en Revista La Trama, 17, UNR (en prensa). 
En esa representación negativa puede aparecer enunciativamente el «intento» por doblegar al adversario, u opositor político o social o en su metáfora extrema, «destruir al enemigo». Por eso, el fracaso de lo político se materializa cuando esa imprecación pasa del plano simbólico del discurso al plano del acto. Porque, como señalaba Hanna Arendt: «toda violencia es muda» ${ }^{19}$.

Insistimos que el orden clasificatorio de la comunicación de gobierno en sus facetas (a) administrativa, (b) institucional y (c) política, no debería hacernos perder de vista que se trata de dimensiones que funcionan simultáneamente, que se superponen o establecen relaciones de jerarquía o de figura-fondo entre sí. Esos juegos significantes configuran la condición estilística de esos textos.

\section{Periodización de los estilos gráfico-discursivos de la comunicación de go- bierno}

\subsection{Una «prehistoria» de la comunicación de gobierno}

La condición histórica del género aviso de gobierno permite describir sus procedimientos gráfico-argumentativos en una serie diacrónica. Así, en la historia de los avisos de gobierno en la prensa argentina ${ }^{20}$, desde mucho antes que pudiera describirse algo equivalente a una estrategia explícita de comunicación de las sucesivas administraciones se venían publicando balances, edictos, llamados a licitación o información sobre servicios públicos.

A partir de esa obligación administrativo-institucional se generó una trama de géneros «oficiales» a utilizar que, según los períodos de que se trate, podían estar incluidos o no, en una estrategia de comunicación específica. Es decir que si un gobierno decidía no privilegiar una estrategia de comunicación particular, de todos modos aparecían avisos que comunicaban su accionar.

Hacia 1880, si ocurría una controversia entre las autoridades y una empresa, las declaraciones de ambas partes aparecían incluidas en el cuerpo informativo. El gobierno, la empresa y el medio interactuaban «en el mismo nivel»; en ese registro, los campos que tenían que ver con la vida urbana, política y social, en general, aparecían mimetizados.

La referencia al año no es arbitraria. Para ese momento, la comunicación de producto, cuyo momento fundacional ubicamos en 1864, ya tenía en nuestro país un camino recorrido. La figura del «inventor-emprendedor» y el tema del «autoforjamiento» -propio de muchos relatos sobre inmigrantes que llegaron a distintos países en períodos de consolidación nacional-, acompañan también al norteamericano Melville Se-

19 Arendt, H. (1993): La Condición Humana, Buenos Aires, Paidós, 2005, 44.

20 Fernández J. L. Director Proyectos de Investigación, UBA: «La Autonomía de la Ciudad de Buenos Aires en su Comunicación Institucional», 1998/99 (UBACyT AS 07); «Estilos de comunicación institucional en medios gráficos», 1995/97 (UBACyT CS 036). 
well Bagley. A partir de su trabajo en una droguería, elaboró un tónico refrescante basado en las cortezas de las naranjas amargas, tipo «bitter», que se presentó comercialmente como una solución a los problemas estomacales. El lanzamiento de Hesperidina, autoproclamada como licor de moda, fue el inicio de la empresa Bagley que se convirtió en una de las más importantes y tradicionales del rubro alimenticio en la Argentina. El éxito de la bebida llevó a la aparición de imitaciones; su lucha judicial para que le reconocieran la invención del producto y el esfuerzo para que se organizara un sistema de patentes y marcas que defendiera sus derechos, llevó a que se creara esa dependencia en 1876 y que, en reconocimiento su esfuerzo, Hesperidina recibiera el número 1 en la lista de marcas argentinas.

Hesperidina lanzó entonces la primera campaña publicitaria, en sentido moderno, de la Argentina: en los cordones de las aceras aparecía escrito en letras negras la palabra Hesperidina. Este mecanismo se continuó durante dos meses hasta que finalmente, un anuncio aparecido en los diarios reveló la identidad del producto. Se había lanzado la primera campaña-enigma, procedimiento de larga vigencia en la publicidad. El cambio de soporte, del cordón de la vereda al diario, implicó también un novedoso recurso transpositivo: los avisos de Hesperidina aparecían publicados en los bordes de las páginas, como juego retórico que remitía al soporte original. El misterio se develó el 24 de diciembre de 1864, cuando en el diario La Tribuna apareció el aviso anunciando la marca, con la ilustración de su particular envase con forma de barril ${ }^{21}$.

Simultáneamente aparecían avisos de profesionales anunciando sus servicios, pedidos u ofrecimientos de personal para el trabajo en las casas, compra y venta de propiedades, etc. a modo de los actuales avisos clasificados, pero con falta de jerarquización y diferenciación con respecto al cuerpo informativo del diario por la ausencia de un concepto de diseño.

Para el año del Centenario de la República Argentina, en 1910, encontramos un conjunto de piezas que podemos clasificar genéricamente como comunicación institucional. Como una especie de grado 0 de este tipo de comunicación, la mayoría de los avisos presentaba una referencia lateral al gran festejo patrio. Apenas algún adosado gráfico o una adecuación del argumento de venta en el que se vinculaba consumo y festejo. En esa trama discursiva aparecieron también otros registros más ostensivos, con motivos gráficos que remitían tanto a una estatuaria, como a la construcción de un panteón de héroes.

Como ejemplo de ese lento proceso en el que la comunicación institucional fue gestando un espacio propio, en 1910 encontramos también los avisos de Cigarrillos Centenario y de Cerveza Quilmes. La presencia de fotografía en el aviso de Cigarrillos Centenario es un caso excepcional dentro del corpus de la incipiente comunicación institucional del período. En el nivel del texto, el anunciante informaba sobre una iniciativa cultural en homenaje a la fecha patria. Pero haciéndose cargo

21 www.hesperidina.com.ar Web consultada el 2 de febrero de 2011. 
de los «tempranos» temores de la sociedad sobre los efectos del deslizamiento entre discurso institucional y discurso publicitario, también alertaba respecto de que «el carro (alegórico) no contiene palabra alguna de reclame ${ }^{22}$ y sí solamente la inscripción CENTENARIO ARGENTINO 1810-1910».

En el caso del aviso de Cervecería Argentina «Quilmes» para Cerveza Quilmes Centenario aparecían un conjunto de frases con gran variedad de tipografías y métricas, donde se alternaban frases de registro patriótico con otras de orientación persuasiva. La «sencillez» del aviso de Quilmes Centenario replicaba las formas con las que la mayoría de los diarios de la época podían titular.

Como único ejemplo de comunicación de gobierno, para esa fecha aparece la Convocatoria al Pueblo de la Comisión Nacional del Centenario, publicada en páginas interiores de los diarios, casi sin diferenciación gráfico-textual respecto del cuerpo periodístico del diario. El aviso estaba ordenado en tres columnas a un cuarto de página; el texto, dividido en dos partes, introducía los argumentos laudatorios para luego explicar los aspectos organizativos del acto conmemorativo.

Fig. 2 Cerveza Quilmes Centenario. Diario La Nación, 27/5/1910

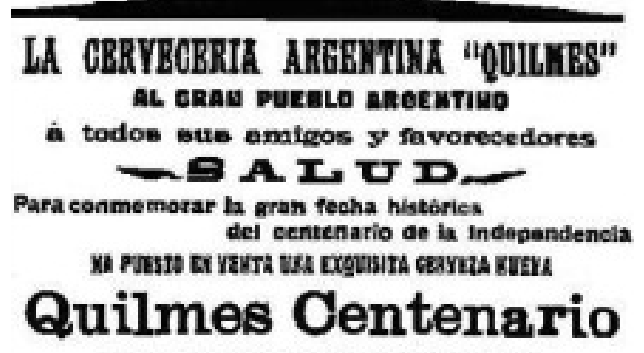

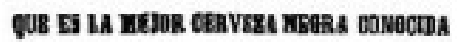

Fig. 3 Comisión Nacional del Centenario. Diario La Nación, 23/5/1910

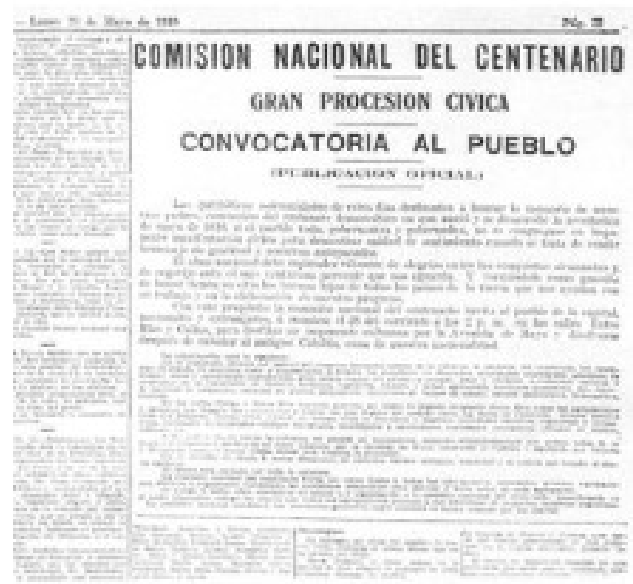

El despliegue gubernamental realizado para el evento (exposiciones internacionales, inauguración de monumentos, colecciones, etc.); el crecimiento de la comunicación de empresas y comercios en los diarios y el estado general de la industria gráfica -que incluía revistas paradigmáticas en cuanto a la cantidad y calidad de avisos publicados, como el caso de Caras y Caretas $^{-23}{ }^{23}$, contrastan con la presencia de este único aviso de gobierno.

22 Así se denominaban los anuncios publicitarios en ese período.

23 Caras y Caretas apareció en 1898 como semanario con una tirada de 15.000 ejemplares; en 1904 alcanzó la cifra de 80.700 y en 1910 llegó a 110.700. Los primeros números tenían 24 páginas y 6 eran de publicidad. Para el Centenario la publicidad ya ocupaba casi un $40 \%$ y en 1920 , la mitad de 
Recién en 1920 aparecen fenómenos novedosos tanto a nivel de la comunicación comercial, como de la comunicación de gobierno. En el caso de la comunicación comercial, se publican un conjunto de piezas alusivas a las celebraciones patrias y a las fiestas de fin de año que se organizan como comunicación institucional pura, sin mostración ni mención de las características de los productos, y con prevalencia de la imagen de la marca.

Fig. 4 Vermouth Cinzano. Diario La Época, 23/5/1920

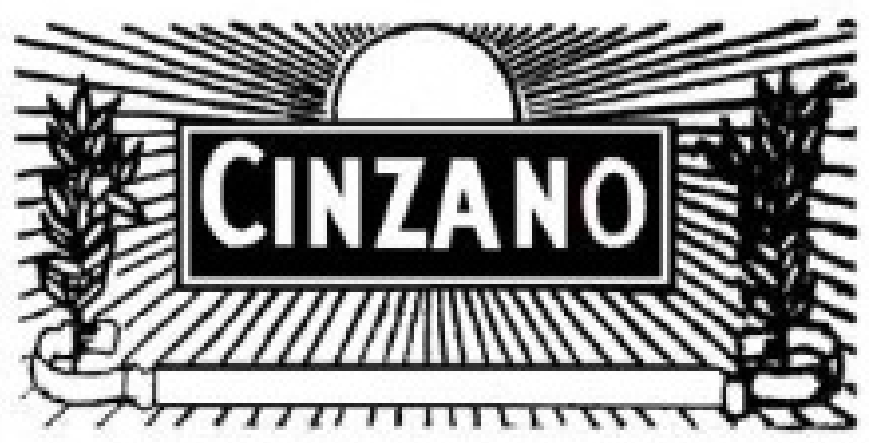

En el caso de la comunicación de gobierno, durante ese mismo año la Municipalidad de la Ciudad de Buenos Aires, a través de la Dirección de Bromatología de la Secretaría de Salud Pública, emprende una serie de inspecciones en distintos establecimientos de producción alimentaria. Los diarios informaban sobre la clausura de empresas y las contravenciones halladas en otras, y en los días subsiguientes aparecieron comunicaciones de dichas empresas que oscilaban, genéricamente entre el aviso y la solicitada, algunas bastante importantes, donde «aclaraban» que fueron inspeccionadas por la Dirección de Bromatología y que no se había encontrado ningún elemento irregular en su producción. Por lo que las firmas seguían garantizando la calidad de sus productos e incluso, algunas de ellas, invitaban a la población a visitar sus instalaciones.

Como señalamos, se trataba de un movimiento no vinculado directamente a la venta que se estructuraba a partir de juegos de diferenciación gráfico-textual entre los distintos tipos de instituciones y la prensa. Las causas y consecuencias de esos procedimientos se vinculan a procesos de construcción discursiva de formas de identidad de empresas, gobiernos y organizaciones, respecto de la prensa. Estas instituciones comenzarán a instalarse paulatinamente a través de un espacio propio y pago, con procedimientos que en gran parte abrevarán en géneros discursivos preexistentes como la carta, el balance, la proclama, etc. Ya no será la palabra del medio la única que podrá intervenir para dar cuenta de la acción de las institucio-

la revista. En: SeOAne M. y SAnta MARÍA V. (2008): La tragedia y la comedia de la Argentina, Buenos Aires, Editorial Caras y Caretas, 6-22. 
nes; se establecerá un corrimiento que implicará un enorme cambio de posición en la relación del medio, de la empresa y del gobierno, respecto al lector ciudadano, usuario o consumidor.

En la transición hacia otro hito comunicacional que recién ubicaremos en 1940, aparecen avisos de organismos nacionales y municipales donde si bien el aviso aparecía recortado, no producía el efecto de que la institución estuviese imponiendo una norma estilística propia. Inclusive, el mismo aviso podía aparecer en diferentes medios de prensa con distintos diseños, seguramente a cargo del propio diario.

Finalmente, las instituciones/empresas comienzan a independizar su posición enunciativa de la información y opinión del medio; y la consolidación de ese espacio gráfico institucional autofinanciado permitirá, más adelante, la aparición de la diferenciación estilística interinstitucional.

En mayo de 1940 se publica en el tradicional diario La Nación una solicitada de dos páginas y media titulada «La intervención en Santiago del Estero ha terminado su cometido». Se trata de un aviso de gobierno con un registro propagandístico fuerte; mixtura desde lo formal un formato de tipo periodístico que mantiene las ocho columnas, la misma tipografía de los textos del diario, fotografías de las autoridades de la intervención y de las obras ejecutadas. Además aparecen cuatro cuadros en facsímil, con información económica y el nombre de la agencia de publicidad. Una guarda bordea todo el aviso.

El texto expone los «logros» de la intervención nacional a la provincia de Santiago del Estero, en el marco del llamado a elecciones democráticas para regularizar la situación institucional de dicha provincia. Se produce una aparición de la palabra de gobierno como gesto autovalorativo de fuerte componente propagandístico. Desde esa madurez comunicacional parece decir: «gobernamos Santiago del Estero, no sólo la Nación, y éste es el resultado de nuestra acción de gobierno, el mejor resultado posible», instalando así al gobierno central por sobre las provincias.

Este texto carecía aún de los juegos gráficos que aparecerán más tarde, aunque esa forma, con el despojamiento propio de la solicitada, tuvo vida central hasta hace unos años, y aún subsiste como género específico de la comunicación institucional. A la vez, aparece como una nueva etapa que instalará a la comunicación de gobierno como una categoría discursiva socialmente reconocida.

El próximo estadío es el mandato de Juan D. Perón (1946-1954), considerado un momento paradigmático de la comunicación de gobierno. La dificultad para el abordaje de este caso históricamente crucial del discurso político argentino, puede resumirse a partir de su carácter polémico, a partir de una insistencia que «no cesa de desafiar el tiempo, irrumpiendo cada tanto en el espacio político y cultural argentino a través de distintas versiones y géneros narrativos» ${ }^{24}$.

24 Campos, A. (2009): La imagen justa. Cine argentino y política, Buenos Aires, Colihue, 54. 
Algunas perspectivas reduccionistas suelen poner eje en lo que consideran la manipulación de los medios de comunicación a través de Raúl Apol, el entonces Secretario de Prensa de la Presidencia. Sin embargo, y reconociendo el carácter centralizado que adquirió el manejo y desarrollo del sistema de medios durante el gobierno peronista, censuras incluidas, la homogenización discursiva no parece haber estado soportada en su comunicación en la prensa. Al analizar los avisos de esa etapa, lo que asoma no es uniformidad, sino una convivencia compleja de los estilos de la comunicación gráfica de la época. Estilos que, por otra parte, mostraban una transición del lenguaje publicitario «referencial» a uno «estructural o de la significación $»^{25}$, reconfigurados a partir del propio modo de decir del gobierno peronista. Tópicos como:

la didáctica alfabetizadora afectiva-infantil, la didáctica adulto-racional a través de la cuál se comunicaba a los trabajadores los avances del proceso de industrialización y la distribución de la riqueza ("la grandeza de la patria y la felicidad del pueblo") y otra en que afiches y avisos desarrollaban una clara intención persuasiva ${ }^{26}$;

aparecían modalizados a través de distintos estilos gráficos y textuales como el art decó, presente en el escudo peronista como una versión estilizada del escudo nacional argentino; la ilustración americana, que generó el crecimiento de la imagen como elemento central del aviso publicitario ${ }^{27}$; la cita al neoclasicismo a partir de la recuperación de las figuras posadas, esculturales, modélicas a partir del uso del sombreado; la tematización del héroe patriótico y de las virtudes éticas; ciertos elementos futuristas para la exaltación del progreso; el uso de la fotografia realista, etc. ${ }^{28}$.

Como posible efecto de sentido, se trató de una heterogeneidad compositiva que artículo con diversos públicos emergentes. Y desde la comunicación misma, a partir de su condición multifacética y desbordante y de su fuerte impronta disuasiva, alimentó el imaginario de sus adherentes, pero también de sus adversarios y enemigos.

25 CARO, A. (1994): La publicidad que vivimos, Madrid, Eresma y Celeste Editores, 120.

CAMPOS, A. (2009): op. cit., 37

27 Representada en la Argentina por dibujantes como Raúl Manteola, autor del retrato más difundido de Eva Perón en Steimberg, O. Y TRAVersa, O. (1997): Estilo de época y comunicación mediática Buenos Aires, Atuel, 68-69

28 SzNAider, B. Y Koldoski, D. (2005): «Imágenes del Peronismo: La fotografía en un caso de comunicación institucional de gobierno», en Revista Virtual Question 8. Buenos Aires, Facultad de Periodismo y Comunicación Social, UNLP, http://perio.unlp.edu.ar/ojs/index.php/question/issue/view/19 Web visitada el 29 de diciembre de 2010. 


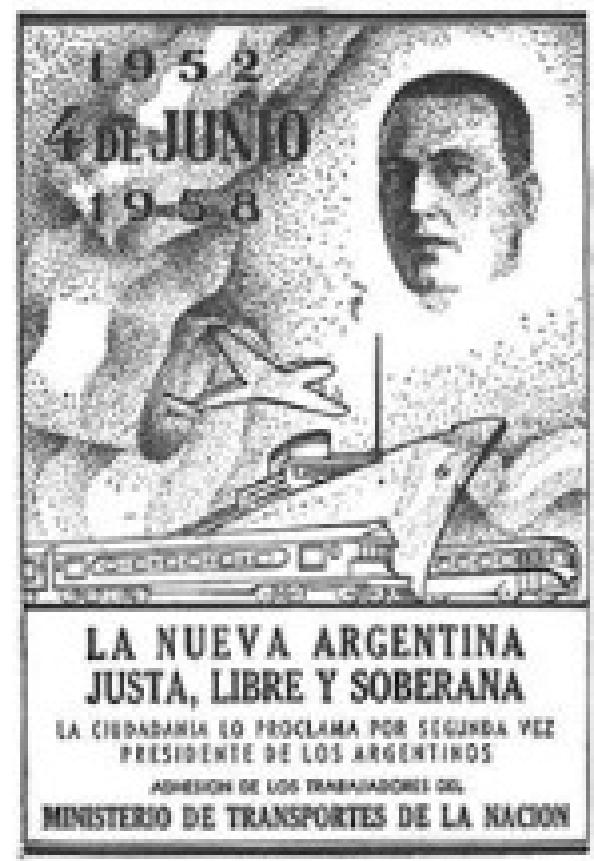

Fig. 5 Ministerio de Transportes de la $\mathrm{Na}$ ción. Diario Democracia, 4/6/1952

\subsection{Vanguardia comunicacional y utopía urbana}

En 1971 se produjo una instancia que condensó y expandió las condiciones de la comunicación institucional de gobierno. Un momento de vanguardia comunicacional respecto de otros centros urbanos, cuando la ciudad de Buenos Aires sale de lo que, desde nuestras investigaciones, definimos como una larga «prehistoria» de la comunicación de gobierno. Ese momento antecedió cronológicamente a la revolución cultural de Tierno Galván en Madrid, a los desarrollos de la marcapaís/marca-ciudad de Toni Puig Picart para Barcelona, y del «sello Miró» que identificará en adelante a la España turística en el mundo.

La Municipalidad de la ciudad de Buenos Aires elabora un plan maestro integral de identificación visual en el que se aplica un sistema de diseño que abarca desde la construcción del esquema de la comunicación gráfica, a la pintura de los edificios y vehículos municipales, la vestimenta del personal de servicio de calle y la señalización vertical de la ciudad ${ }^{29}$.

29 Gestión de Saturnino Montero Ruiz (1971-1973), intendente de la ciudad en momentos en que gobernaba el país Agustín A. Lanusse, último presidente militar del ciclo dictatorial que culminó en las elecciones democráticas de marzo de 1973. El plan fue desarrollado por los diseñadores gráficos Ronald Shakespeare y Guillermo González Ruiz, pioneros en la expansión del diseño gráfico en la Argentina. 
Toda la comunicación de ese breve período se puede describir por procedimientos generales de imposición de normas gráficas:

Se trató de una autonomización del discurso municipio-ciudad en el marco de una perspectiva utopista que imponía su voluntad de control del espacio visual global y generaba una tematización específica del dominio del espacio urbano a través de procedimientos de homogenización gráfico-textual. ${ }^{30}$

Fig. 6 Municipalidad de la Ciudad de Buenos Aires.

Gestión Montero Ruiz. Diario Clarín (a) 2/6/71; (b) 12/5/1971
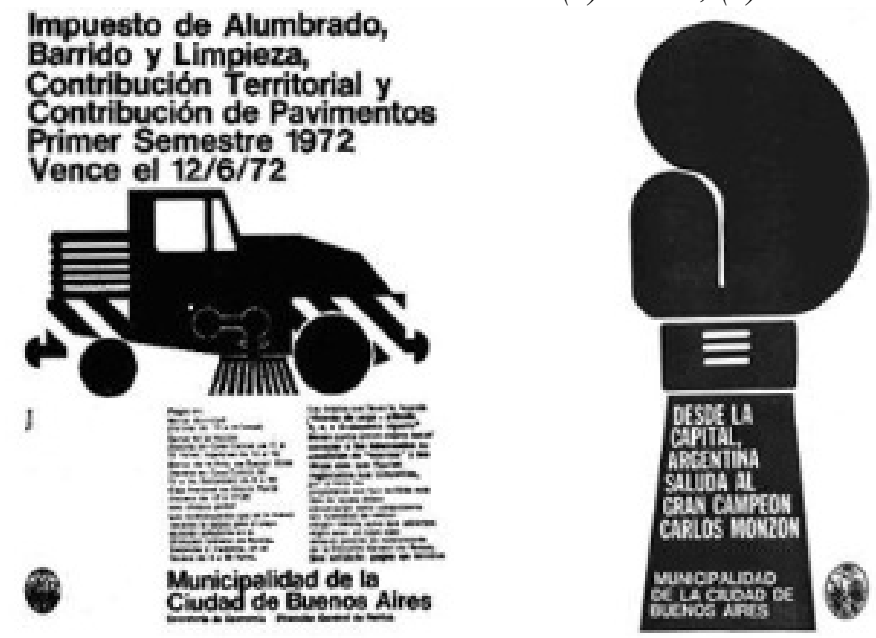

La fuerza del sistema gráfico-textual del plan de Montero Ruiz, con su «efecto de descarga racional de proyecto de comunicación sobre una gran urbe organizada» ${ }^{31}$, atravesó sucesivos gobiernos de la Ciudad, soportado en la señalización vertical en la vía pública. Y aunque aparecieron diversos intentos por abandonarlo a nivel gráfico, el modelo siguió aflorando como especie de «reservorio estilístico» en los distintos momentos o niveles de las transiciones políticas, como índice de su densidad significante.

Un elemento importante de la imagen de gobierno dentro del modelo Montero Ruiz fue el trabajo sobre el escudo de la Ciudad, un escudo de armas que se fue modificando en su diseño a lo largo de casi trescientos años. Su versión abstracta y racionalista funcionó como marca transpositiva que unificó el mobiliario urbano con la gráfica gubernamental y fue retomada y recreada en dos gobiernos posterio-

30 FERNÁNDEZ, J. L. y SZNAIDER, B. (2008): «Retornos de la gráfica vanguardista en un plan visual urbano» en Figuraciones 4, Buenos Aires, IUNA, www.revistafiguraciones.com.ar/numeroactual/index.php?idn=4\&arch=1 Web visitada el 19 de agosto de 2011.

31 FERnÁNDEZ, J. L. Y SZNAIDER, B. (2008): op. cit. «Retornos de la...» 
res: el de Fernando de la Rúa (1996-1999) -primera autoridad de la Ciudad elegida por voto popular-y el de Mauricio Macri (2007-continúa).

Fig. 7 Escudo y logotipos de la Ciudad de Buenos Aires: 1926, 1971, 1998, 2007.
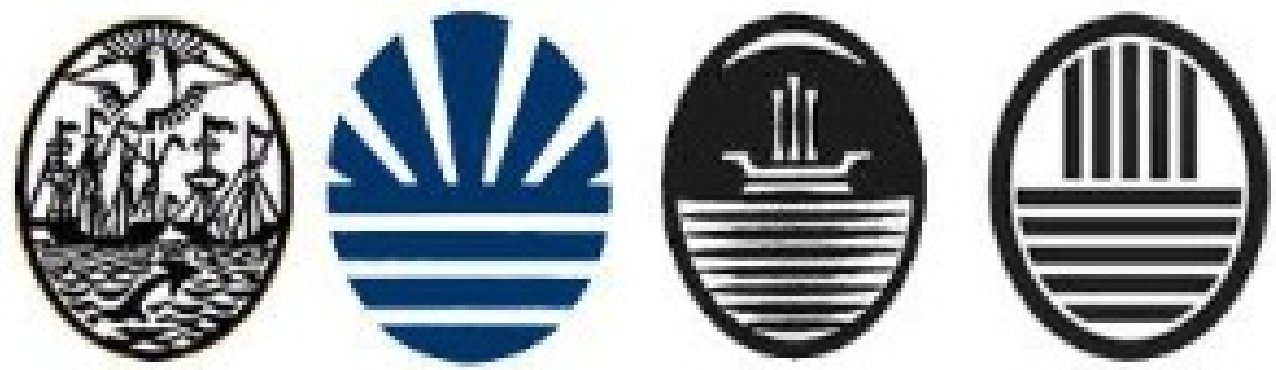

Si ponemos en relación la comunicación de gobierno del período peronista (1949-1955) con la de Montero Ruiz (1971-1973), encontramos elementos de exceso productivo que las emparenta; pero se diferenciarán por la condición heterogénea y sentimental de la primera y la característica normada y racionalizante de la segunda. Mientras la comunicación del peronismo construyó centralmente a diversos públicos, la de Montero Ruiz puso a la comunicación misma como referencia que podía modificar la vida urbana.

Es indudable que la gestión Montero Ruiz estuvo inserta y fue influida por el contexto modernizador de la época. Pero la novedad se asentó en la condición utópica de su plan, quizás el último estertor de un keynesianismo latinoamericano en el que se pensaba que los Estados debían hacerse presentes a través de proyectos a mediano y largo plazo para dar soluciones económicas y sociales, y cuyo fundamento era una concepción estructural del desarrollo ${ }^{32}$.

La instancia de quiebre definitivo del sistema Montero Ruiz se produjo en 1989 cuando durante la gestión del intendente de origen peronista Carlos Grosso, se intervino sobre el diseño gráfico-estilístico de la comunicación de gobierno. En la gestión de Grosso (1989-1992) se muestra la voluntad de rediseñar en un sentido ahora relativamente utópico, el conjunto del contacto comunicacional con la población gesto que se mantendrá, aunque menos acentuado, en las gestiones peronistas que lo sucedieron ${ }^{33}$.

Aparece un efecto de transformación y de ruptura en la comunicación institucional, con componentes de creatividad, fuerte efecto de escritura y muy especialmente de innovación en la línea gráfica, donde se pasa del logotipo al isotipo, del mundo de la letra al de la imagen. En los avisos se incluyó, a modo de

32 Falleto E. (1996): «La Cepal y la Sociología del Desarrollo», Revista de la Cepal, 58, Santiago, Cepal, 191-204.

33 Gestiones de los intendentes de la ciudad de Buenos Aires Saúl Bouer (1992-1994) y Jorge Domínguez (1994-1996). 
sello, un perfil de la ciudad de Buenos Aires en el que se recortaban monumentos públicos prototípicos como el Obelisco, el Cabildo, el Concejo Deliberante, el Planetario. Pero también se reconocía el perfil del edificio IBM, hasta hace pocos años distintivo entre las siluetas de los edificios corporativos que emergen del barrio porteño de Catalinas. Sobre las siluetas se recortaba el nombre Buenos Aires y por debajo aparecía la denominación «Municipalidad de la Ciudad», un juego retórico sobre el significante que generaba efecto de acercamiento entre la institución y la población al despegar a la Municipalidad de su estatuto jurídico y reenviarla al espacio común de los habitantes de la ciudad.

La comunicación de ese período se caracterizará por un «juego de negociación», un esfuerzo apelativo destinado a comprometer a la población en un cambio de hábitos para la transformación de la administración municipal, pero en un registro coloquial y con marcas de humor. Por ejemplo, el eslogan: «Si usted recorta este aviso nosotros recortamos gastos» acompañaba la agenda de vencimiento de los impuestos municipales. En esta pieza se informaba de un recorte al presupuesto en publicidad; por lo que se le solicitaba al contribuyente que conservara el aviso para no tener que volver a publicarlo.

Otras eslóganes: «Atención», aviso en el que se informaba sobre la extensión del horario de atención de los hospitales públicos; «Flor de idea», un sistema de padrinazgo privado para el cuidado de plazas y parques; «Los vecinos le dan audiencia a la Municipalidad», para promover espacios de diálogo, negociación y cooperación entre y con los vecinos, etc. Además, aparecerá un rasgo que había sido propio de la comunicación de gobierno del Partido Radical en la ciudad de Buenos Aires (se presenta más adelanta), como es la acentuación de la comunicación de acciones de manera diferenciada para distintos segmentos de vecinos. Esta segmentación seguramente puede ser leída como efecto de los procesos de glocalización, es decir, del impacto de las transformaciones globales en escenarios locales que debilitaron ciertas categorías republicanas. Como resultado, la dificultad de construir y de interlocutar con un sujeto urbano íntegro, que es a la vez ciudadano, vecino, contribuyente, habitante, transeúnte, conductor, etc.

En la comunicación de Grosso también aparecerá la etiqueta: «Hacia una nueva ciudad» que tiene origen en una serie de avisos a página completa donde comienza a plantearse el programa de privatizaciones y concesiones, una transformación estructural en los modos de gestión y administración de la Ciudad. Mientras las marcas gráficas y los títulos-eslogan orientan el sentido del programa institucional, los desarrollos de los textos se instalan desde una persuasión suave que tematiza la necesidad de transformación como efecto de un consenso construido en el que la institución ya no impone, sino que comparte. Aunque la institución gobierno tiende a separarse de la institución municipalidad para exponer su rumbo programático, lo hace desde un doble estatuto enunciativo, donde los textos argumentativos parecen querer compensar la presencia contundente de la institución en su comunicación. No 
se trata sólo de un gobierno haciendo avisos, sino que quedaba expuesto el efecto de la acción político-comunicacional a partir del esfuerzo argumentativo para describir y explicar el rumbo asumido.

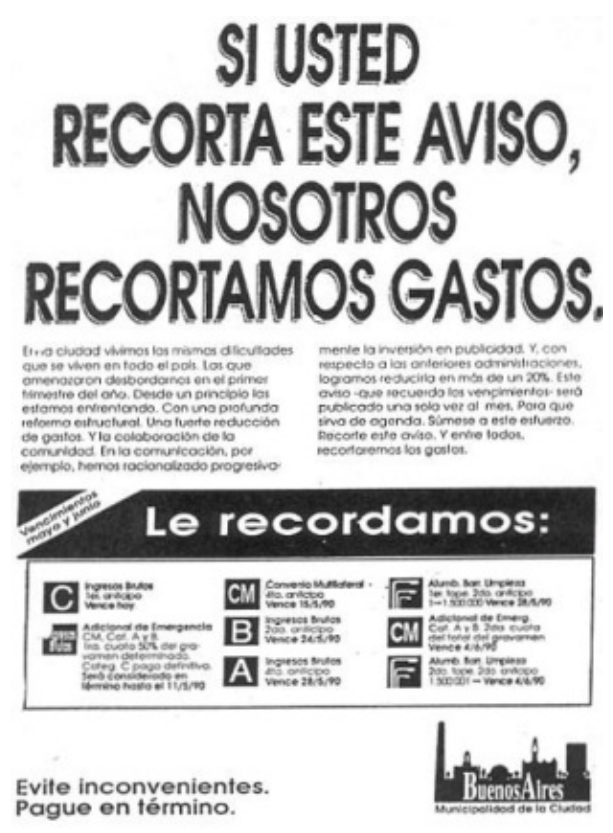

Fig. 8 Municipalidad de la Ciudad de Buenos Aires. Gestión Grosso. Diario Clarín, $2 / 5 / 1990$

Los gobiernos peronistas que completaron la gestión de Grosso -quien debió renunciar acosado por denuncias sobre corrupción vinculadas, justamente, al proceso de privatizaciones y concesiones-, funcionaron como una transición hacia el entronamiento de una figura política que desde hacía más de veinte años tenía protagonismo en la política de la ciudad de Buenos Aires: Fernando de la Rúa.

\subsection{Tensiones entre tradición y cambio en los estilos discursivos}

El primer jefe de gobierno elegido por el pueblo, Fernando de la Rúa (1996-1999), instalado como figura antagónica de su antecesor, el peronista Carlos Grosso, abrevó en las formas comunicacionales propias de su partido, el radicalismo, fuerza política que además dirigió la ciudad de Buenos Aires (y el país) en los períodos 1963-1966 y 1983-1989. En ese último ciclo aparecieron difenciaciones internas. Julio Saguier, fallecido en gestión, recuperó el escudo de armas original que identificaba a la Ciudad como marca de tradición. Mientras quien completó su mandato, el referente juvenil partidario Facundo (Facundito) Suárez Lastra, impuso rasgos discursivos que jerarquizaban, sobre todo, el vínculo con segmentos particulares de la ciudad a través de una gráfica modernizante. 
Fig. 9 Municipalidad/Gobierno de la Ciudad de Buenos Aires.

Gestiones radicales. Diario Clarín: (a) 1983; (b) 1985; (c) 1997
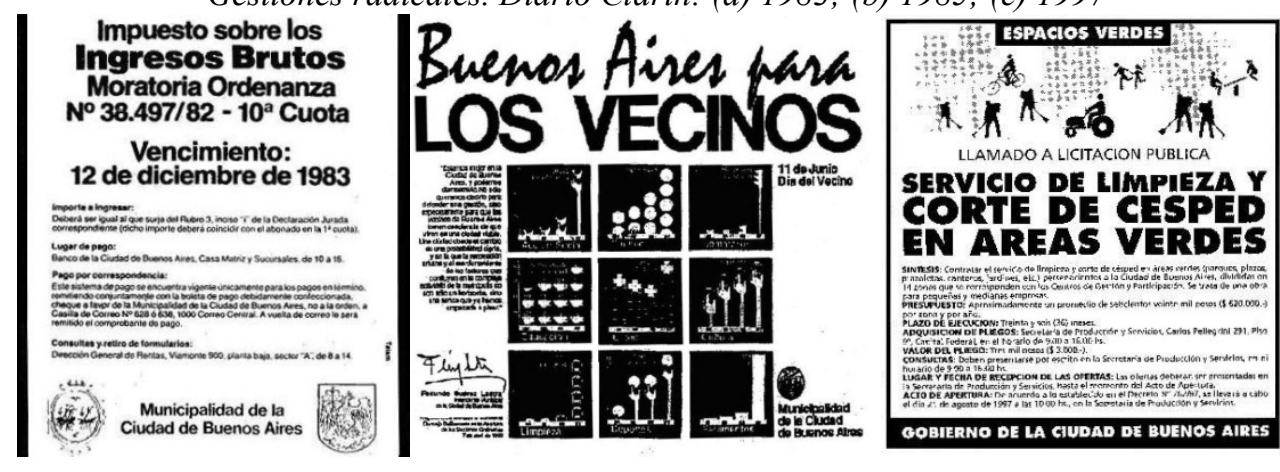

La conquista de la autonomía de la ciudad, en 1996, implicó un cambio de enorme peso político y simbólico. Los ciudadanos porteños pudieron elegir por primera vez, a través de elecciones directas, a su jefe de gobierno. Sin embargo, ese momento de transformación profunda de la institución de gobierno no fue acompañado por una estrategia de comunicación diferenciadora desde el punto de vista estilístico.

Luego de un primer momento de juego con el logotipo entre el nombre de la ciudad y el de la institución de gobierno (Gobierno de la Ciudad), la gestión optó por una racionalidad ordenadora, pero sin marcas diferenciadoras; con una enunciación borrada y neutra, carente de marcas interpelativas y adjetivaciones. Otras características significantes: homogeneidad estilística cuando se trataba de temas administrativos de la ciudad; pero falta de unificación en piezas pertenecientes a otras áreas de gobierno; además, poca cantidad de piezas. En avisos vinculados a temas de esparcimiento, cultura y tiempo libre aparecía, en cambio, una mayor creatividad.

Junto con la pervivencia de una «tradición radical» en la comunicación gráfica municipal, es probable que la búsqueda de diferenciación mediante el recurso de la "sencillez" haya funcionado como una estrategia defensiva, no necesariamente consciente, para oponerse a la fuerza gráfico-argumentativa de gestiones como las de Montero Ruiz y Grosso.

Pero además, en parte por la necesidad de proyección política personal del jefe de Gobierno Fernando de la Rúa, luego presidente de la República, y en parte por el proceso de crisis de la representación político-partidaria, aparece un borramiento de la institución a favor de una personalización e individuación del mandatario que buscará generar cercanía y empatía entre el funcionario/candidato y la población.

Para ejemplificar esa estrategia interesa destacar una pieza de ese período que, además, constituye probablemente una bisagra hacia una nueva etapa de la comunicación de gobierno en la Ciudad, en la que la dimensión publicitaria aparecerá en 
superficie, como un componente inescindible de las modalidades de la comunicación de los temas y asuntos locales.

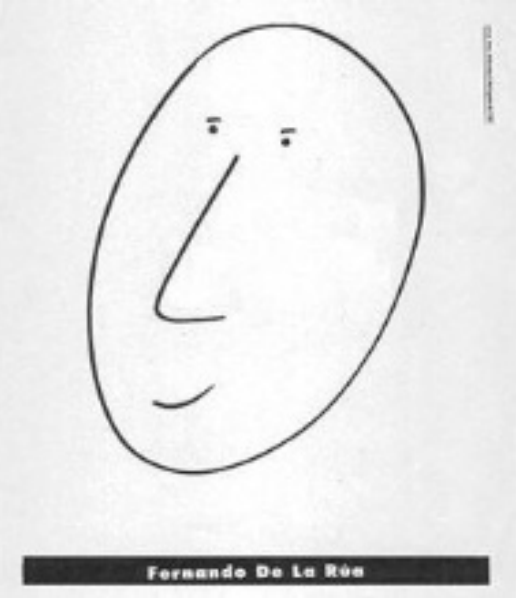

Fig. 10 Gobierno de la Ciudad Autónoma de Buenos Aires. Gestión De la Rúa, Diario Clarín, $6 / 8 / 1997$

Se trata de un aviso de balance publicado con motivo de cumplirse un año de su gestión de gobierno que ocupaba cuatro páginas completas, iniciando con la ilustración en página par y cerrando con la sentencia: «Hace un año decidimos entre todos que las cosas se pueden hacer. Y bien» y en el zócalo, la firma institucional Gobierno de la Ciudad de Buenos Aires. El texto interno (páginas parimpar) guardaba todas las formas estilísticas que la gestión utilizaba tradicionalmente para informar y describía el conjunto de obras realizadas. Para darle mayor jerarquía y énfasis, cada frase iniciaba con la fórmula: "Qué hicimos para...». Pero los puntos de ruptura estaban dados obviamente por la caricatura que simulaba el perfil del jefe de Gobierno; por el título que abría el texto de la segunda página del aviso: «Le explico por qué, en todo este año, no tuve tiempo de sacarme una buena foto»; por el uso de una primera persona que construía diálogo de uno a uno; y por la presencia de su firma caligráfica.

Toda la pieza funcionó como un recurso extraordinario destinado a modificar la percepción de la población respecto de los atributos personales del jefe de Gobierno, caracterizado por un estilo personal conservador y distante y desde lo argumentativo, con elementos propios de cierto institucionalismo vacuo. El estilo del aviso tuvo su expansión en la campaña a presidente de De la Rúa en un spot televisivo que generó fuerte impacto: «Dicen que soy aburrido...», en el que se construía como oposición a la denunciada frivolidad del entonces presidente Carlos Menem. De la pertinencia de este tipo de piezas plantearemos algunas ideas en las conclusiones.

Señalamos que a partir de la gestión De la Rúa, se produce un cambio en el tipo de comunicación para la Ciudad (que obviamente la excede, pero que tendrá 
características particulares). Ya no sólo la dimensión publicitaria aparecerá en superficie, en el sentido de que sus recursos expresivos, en sentido amplio, quedan expuestos, sino que el aviso en la prensa pasará a ser un recurso más, ahora subordinado a un mix de medios que, según los distintos gobiernos, jerarquizará distintos soportes y dispositivos y donde además, el color pasará a jugar un papel identificatorio central.

\subsection{Concepto-marca e identidad institucional}

Tres gestiones sucedieron a De la Rúa: Aníbal Ibarra (2000-2006), Jorge Telerman (2006-2007) y Mauricio Macri, actual jefe de Gobierno reelecto. La de Ibarra se caracterizó por la utilización de un logotipo a modo de concepto-marca que remitía a la manera de nombrar los dominios de Internet y que articulaba con la puesta en marcha del website institucional, una transformación político-comunicacional de gran impacto respecto de los modos de interactuar entre la institución de gobierno y la población. La imagen visual integraba diseño, comunicación y gestión y a través de ese conceptomarca generaba un signo identificador básico que imponía relevancia y continuidad en el tiempo a la promesa de valor asociada a la institución ${ }^{34}$.

Fig. 11 Logotipo Gestión Ibarra

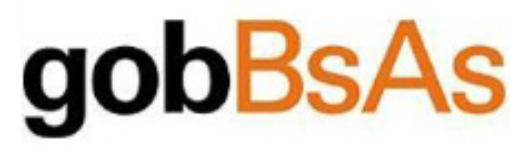

A la vez, las formas de gobierno electrónico con sus procedimientos de interactividad e hipertextualidad, generarán procesos de reconfiguración de la percepción del espacio-tiempo. Cambios de estructuración y reestructuración de recorridos, de continuidades, de escala, de lentificación o aceleración, de copresencia, de densificación de intercambios, etc. a través de los cuáles los sujetos elaboramos nuestra inscripción simbólica en el mundo de los objetos, así como establecemos vínculos con otros sujetos e instituciones.

La identidad gráfica generada durante la gestión de Ibarra no será modificada completamente hasta la llegada de Mauricio Macri. El gobierno de Telerman, una transición para completar el mandato de Ibarra ${ }^{35}$, estuvo signada por cierta debilidad institucional. En esa línea, Telerman lanza la campaña Actitud Buenos Aires con su logo «(a+BA)», buscando imprimirle un sello propio a la gestión.

\footnotetext{
${ }^{34}$ Costa, J. (1994): La imagen de marca. Un fenómeno social. Barcelona, Paidós Diseño, 41

${ }^{35}$ La tragedia ocurrida en el local bailable Cromañón en diciembre de 2004, causó la muerte de 193 personas y 1432 heridos e implicó la destitución de Ibarra luego de que en el juicio político iniciado por la Legislatura de la Ciudad se lo encontrara culpable por mal desempeño de sus funciones. Fue remplazado por su Vicejefe, Jorge Telerman.
} 
De todas maneras, su gobierno conservará elementos del «estilo Ibarra»: se mantendrá la firma con el logotipo «gobBsAs», pero relegado a un segundo plano al desplazarse a la izquierda de las piezas publicitarias y reducir su tamaño. El corrimiento enunciativo, supone además la diferencia entre el «(a+BA)» de Telerman como firma / marca / gestión; del «gobBsAs» de Ibarra como firma / marca / institución. Pero la permanencia del logo de Ibarra en la gestión de Telerman, aunque sea desplazada, representa la «garantía» de continuidad institucional respecto de la gestión anterior. También se producirán modificaciones en el uso de los colores pero el naranja, característico de la gestión Ibarra, continuará presente.

El logotipo «(a+BA $) »$ puede definirse como concepto-marca a partir de su registro sintético y modular que permitía la identificación. Pero además, imponía una dimensión programática y vincular a partir de las distintas lecturas que habilitaba, con el signo «+» como conector respecto de ciertas acciones políticas, por ejemplo: a+ciudadanía o a+comunas. O amás Buenos Aires.

El objetivo principal de la campaña Actitud Buenos Aires fue generar conciencia en el ciudadano acerca del cuidado de la ciudad y el respeto por el otro. Pero el gobierno se presentaba como un enunciador borrado que apelaba a un cambio de conducta focalizado en los valores desde un lugar abstracto, casi sin referencia temporal o espacial. La dimensión político-institucional parecía quedar subsumida en una demanda ética general, pero sin trama enunciativa que convocase o interpelase posiciones sociales más o menos definibles.

Fig. 12 Gobierno de la Ciudad Autónoma de Buenos Aires,

Gestión Telerman, 2006.

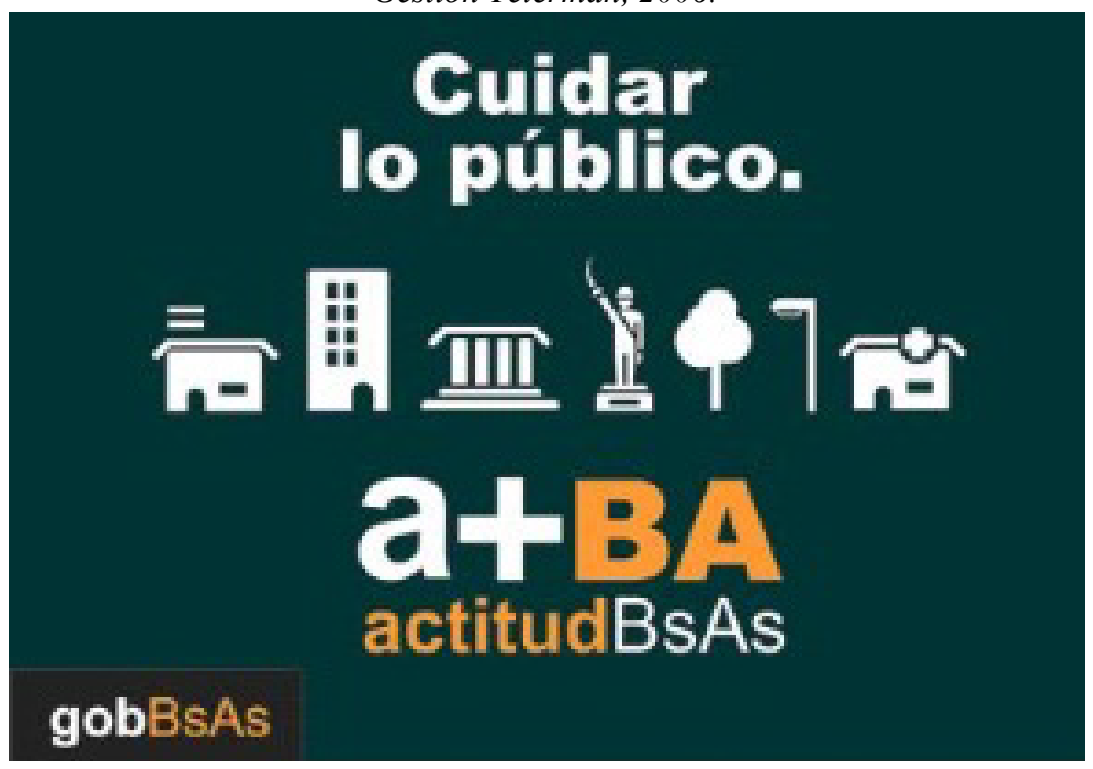


Mientras Telerman utilizó elementos de la comunicación de gobierno para su campaña política a jefe comunal denominando a su lista «+ Buenos Aires», el candidato electo Mauricio Macri, en un movimientos inverso pero equivalente, utilizó elementos identificatorio de su partido político y de la campaña electoral para su comunicación de gobierno.

Fig. 13 (a) Logo partidario PRO (b) Eslogan Gestión Macri, 2007.

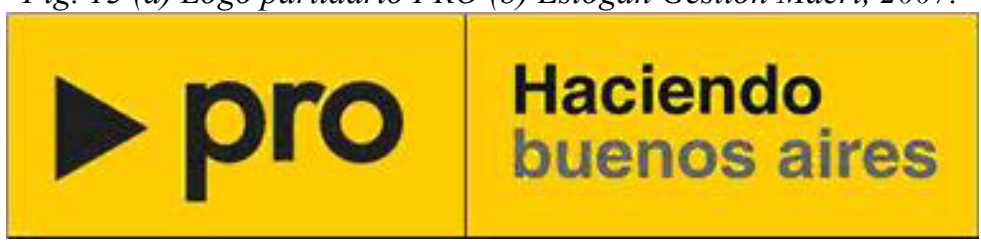

Desde el momento de su asunción, Macri impuso un estilo diferencial de comunicación, manteniendo los colores que identificaban a su fuerza política, con un logotipo que combinaba la preposición «pro» («a favor de»), a la vez apócope del nombre partidario (Propuesta Republicana). El signo gráfico de la flecha, apuntando hacia la derecha, generaba asociación con el botón de play y remitía a la idea de movimiento y acción, en un registro cotidiano y directo, donde la dimensión conflictiva de la ciudad quedaba borrada.

El eslogan distintivo de la primera gestión de Macri fue «Haciendo Buenos Aires», que entraba en diálogo con consignas que habían sido utilizadas en la campaña electoral. En la primera vuelta: «Estaría bueno Buenos Aires si...»; en la segunda: «Va a estar bueno Buenos Aires» ${ }^{36}$. El primer eslogan instalaba un condicional contrafactual que abría a la reflexión. Y el segundo, a una forma cotidiana de estructurar el uso del futuro que desde el infinitivo construía efecto de acción pero como idea general, sin especificar las circunstancias de su realización particular. A la vez, incorporaba una aliteración poetizante entre «bueno y «Buenos» Aires.

La imagen visual del «Haciendo Buenos Aires», caracterizada por su limpieza visual sostenida en el impacto de la «H», parecía reenviar a una estructura que generaba asociación también con un registro «técnico-ingenieril», además, formación profesional de Macri. Junto con el amarillo de base, este elemento definía una mirada sobre la ciudad de acción y atención permanente y continua sobre el espacio público.

A poco de iniciado el segundo mandato del gobierno de Macri, la gestión ha generado una nueva imagen visual en la que, respecto de la anterior, sólo se mantiene el amarillo como fondo de un zócalo que contiene una versión del escudo de la Ciudad de 1920, en lugar del logotipo de barras. El eslogan «Haciendo Buenos

\footnotetext{
${ }^{36}$ En la ciudad de Buenos Aires rige el balotaje que exige más del $50 \%$ de los votos para ganar en primera vuelta.
} 
Aires» fue reemplazado por «Buenos Aires Ciudad» y se ha incorporado uno nuevo: «En todo estás vos». Como imagen modular, aparece una silueta-ventana que se recorta sobre las formas de las iniciales B(uenos) y A(ires) y habilita la mirada hacia diversos motivos de la ciudad: juego, tradición, cultura, historia, derechos humanos, deporte, etc. Además, la A(ires) funciona como viñeta que incorpora una referencia textual que ancla el sentido de la imagen. El protagonismo recae en los habitantes, con sus estilos de vida individuales y prototípicos. La apelación disuelve otra vez toda dimensión conflictiva de la vida urbana para construir un habitar mítico, ceremonial, sin sujeto y sin institución o, al menos, con un sujeto y una institución débilmente perfilados. Ese modo de tematizar el vínculo gobiernopoblación en la escena urbana supone una forma de horizontalización en un registro informal, juvenilizante, afectivo, pero escasamente orientador.

Más allá del carácter mismo de las identidades comunicacionales propuestas por el gobierno de Macri, ambas aparecen como producto de decisiones de coyuntura. Esas decisiones en sí mismas suponen una definición política, en oposición a la condición más permanente y tramada de lo institucional.

\section{Conclusiones}

En nuestro recorrido buscamos circunscribir categorías generales de la comunicación de gobierno definiéndola como una forma específica de comunicación institucional: aquella que pone en el centro la producción de mensajes de un gobierno o gestión, destinados a informar, persuadir y también, generar adhesión entre la población. Señalamos que la comunicación de gobierno siempre aparece atenazada entre registros de lo publicitario y registros de lo político.

También afirmamos que ante el carácter extendido de la comunicación de gobierno, era necesario partir de géneros particulares como modo de comenzar a demarcar, a través de un estudio empírico, rasgos específicos de los procesos de producción de sentido. El contacto con una serie de avisos de gobierno en la prensa nos permitió trabajar con sus imágenes y con sus textos. Pero además, encontramos que al describir la evolución del género describíamos también los procedimientos de diferenciación institucional entre la prensa y los gobiernos, soportados en los modos de procesamiento del dispositivo gráfico ${ }^{37} \mathrm{El}$ dispositivo gráfico impone un primer nivel de significación, a la vez que genera un sujeto particular: una instancia

${ }^{37}$ Dispositivo gráfico como campo de variaciones donde se configuran espacialmente distintos elementos compositivos sobre un plano. Esas configuraciones permiten juegos de inclusión y exclusión (aparecen sólo imágenes o sólo textos); juego de pesos (predominan los textos o predominan las imágenes); relaciones de figura-fondo, de superposición, contigüidad, o encapsulamiento, etc. Fernández J. L. (1994): Los lenguajes de la radio, Buenos Aires, Atuel. 
supraindividual, trascendental o configuración psíquica ${ }^{38}$ que permite la emergencia de un público lector que se pone en contacto con la institución a través de la prensa.

Asimismo, en el recorrido observamos que inevitablemente, los estilos de los lenguajes de cada época se hacen presentes en las formas en las que los distintos gobiernos salieron a comunicar. Pero los propios gobiernos también generan transformaciones estilísticas en los lenguajes institucionales que al regular los intercambios sociales, visibilizan distintas formas de constituir lo público.

Desde el punto de vista de la circulación de los mensajes que emiten los gobiernos, tenemos en cuenta que su eficacia se define en el tipo de lectura, interpretación o valoración que generan estos textos en los públicos concretos; problemas vinculados a las relaciones entre «acción y comunicación» y entre «comunicación y efectos». Esa tensión se observa con claridad, por ejemplo, en la distancia que suele encontrarse entre la prestación efectiva de un servicio y la «imagen» de ese servicio entre los usuarios. Y aunque en este trabajo sólo hemos trabajado en un análisis en producción, el horizonte del reconocimiento y su circulación, debe formar parte de la preocupación de todo gobierno. ${ }^{39}$

Es evidente que en las distintas formas de la comunicación de gobierno está presente un registro funcional a partir del que la institución toma contacto con la población para rendir cuentas de su accionar, advertir sobre ciertas consecuencias conflictivas que puedan producirse al emprender acciones que resultan necesarias, proponer cambios de conducta en la población que redunden en el propio beneficio de ésta, etc. Y que resultado de lo anterior, el gobierno deberá consolidar «una imagen» de sí mismo que no necesariamente genere adhesión pero sí, al menos, «efecto de acción, de gobernabilidad». En ese nivel, la comunicación de gobierno deberá ser evaluada en su capacidad legitimadora y cohesionante, rasgo que nos coloca frente a una dimensión propia de lo político.

Analizada en diacronía, en el tiempo largo de la historia, la comunicación de gobierno nos permite entender de qué manera se fue modificando el modo de interpelación y el vínculo que construyeron los avisos institucionales con los diversos públicos. A partir, por ejemplo, de registros administrativos que tematizaron la relación con un público en tanto contribuyente; o desde registros institucionales que lo convocaron como ciudadano. También aparecieron ciertas formas narrativas que introdujeron dimensiones actanciales destinadas a orientar la acción a través de influencias o móviles, con la ciudad como actante ${ }^{40}$. O una institución que asumía

${ }^{38}$ Carlón, M. (2004): Sobre lo televisivo: dispositivos, discursos y sujetos, Buenos Aires, La Crujía.

${ }^{39}$ Circulación como distancia entre los procesos de producción y reconocimiento discursivos. Verón E. (1993): La semiosis social, Buenos Aires, Gedisa.

${ }^{40}$ Bremond, C. (1982): "El rol del influenciador", en AA.VV., Investigaciones retóricas II, Buenos Aires, Ediciones Buenos Aires. 
una palabra autorreferencial fuerte, entrando en una dinámica de adhesión/oposición que inevitablemente segmentaba a sus públicos.

Desde la comunicación, las instituciones de gobierno «nos llaman», «nos gritan», «nos retienen», «nos sermonean», «nos seducen», «nos imponen». De todas maneras, como ciudadanos/receptores intuimos que los avisos de gobierno no están allí sólo para informar, sino para convencernos de algo. La escena comunicacional nos introduce en un juego que inevitablemente aceptamos: jugar a que (como público) no sabemos que él (el gobierno) sabe que nosotros sabemos.

Esa certeza no debería hacernos perder de vista que se trata de procesos que más allá de su propia intencionalidad, de su eficacia o de las definiciones que las instituciones del Estado hacen sobre lo político, construyen sentido respecto de lo público, de los procesos de representación y de los modos de concebir la interacción y el protagonismo social en el espacio urbano.

\section{Referencias bibliográficas}

ARENDT, H. (1993): La condición humana, Buenos Aires, Paidós, 2005.

BAJTIN, M. M. (Varias ediciones): «El problema de los géneros discursivos» en Estética de la creación verbal, México, Siglo XXI Editores.

BREMOND, C. (1982): «El rol del influenciador», en AA.VV., Investigaciones retóricas II, Buenos Aires, Ediciones Buenos Aires.

CAMPos, A. (2009): La imagen justa. Cine argentino y política, Buenos Aires, Colihue.

CARLÓN, M. (2004): Sobre lo televisivo: dispositivos, discursos y sujetos, Buenos Aires, La Crujía.

CostA, J. (1994): La imagen de marca. Un fenómeno social, Barcelona, Paidós Diseño.

DOMENEACH, J.-M. (1962): La propaganda política, Buenos Aires, Editorial Buenos Aires.

FALleto E. (1996): «La Cepal y la Sociología del Desarrollo», Revista de la Cepal, 58, Santiago, Cepal, 191-204.

FERNÁNDEZ J. L. (1994): Los lenguajes de la radio, Buenos Aires, Atuel.

- (1995): «Estilo discursivo y planeamiento comunicacional», Oficios Terrestres 1, La Plata, Facultad de Periodismo y Comunicación Social, UNLP.

MAQUiAVelo, N. (1989): El príncipe, México, Editorial Porrúa.

SeoAne, M. y SANTA MARÍA V. (2008): La tragedia y la comedia de la Argentina, Buenos Aires, Editorial Caras y Caretas.

SteImBerg, O. (1993): Semiótica de los medios masivos, Buenos Aires, Atuel.

- y Traversa, O. (1997): Estilo de época y comunicación mediática, Buenos Aires, Atuel.

SZNAIDER, B. (2010): «Bicentenario. Pliegues de la Argentina sus avisos institucionales», Revista La Trama 17, UNR (en prensa).

VERÓN E. (1987): «La palabra adversativa. Observaciones sobre la enunciación política», en AA.VV., El discurso político. Lenguajes y acontecimientos, Buenos Aires, Hachette, 13-26.

- (1993): La semiosis social, Buenos Aires, Gedisa

- (2001): El cuerpo de las imágenes, Buenos Aires, Norma. 


\section{Sitios Web}

Burgos, M. y DíAz CAFFerata, S. (2009) «La regulación de la publicidad oficial en Argentina» en Ética, Transparencia, Corrupción y Control Ciudadano, www.asociacionag.org.ar. Web visitada el 19/12/2011.

FERNÁNDEZ, J. L. Y SZNAIDER, B. (2008): «Retornos de la gráfica vanguardista en un plan visual urbano» en Figuraciones, 4, Buenos Aires, IUNA, www.revistafiguraciones.com.ar/numeroactual/index.php?idn=4\&arch=1. Web visitada el 19/8/2011.

SZNAIDER, B. Y KoldosKI, D. (2005): «Imágenes del Peronismo: La fotografía en un caso de comunicación institucional de gobierno», en Revista Virtual Question 8. Buenos Aires, Facultad de Periodismo y Comunicación Social, UNLP, http://perio.unlp.edu.ar/ojs/ index.php/question/issue/view/19. Web visitada el 29/12/2011.

TRAVERSA, O. (2009): «Dispositivo-enunciación: en torno a sus modos de articularse» en Revista Figuraciones, 6, Buenos Aires, IUNA, http://www.revistafiguraciones.com.ar/numeroactual/index.php?idn=6\&arch=1. Web visitada el 16/8/2011. 